\title{
CULTURAL NORM CONFIGURATIONS IN ACEHNESE LULLABY
}

\author{
Devi Pratiwy \\ Universitas Islam Sumatera Utara, Medan, Indonesia \\ devipratiwy@sastra.uisu.ac.id
}

Received: $02 / 12 / 2021$

Accepted: 03/12/2021

Publication: 04/12/2021

\begin{abstract}
This study is aimed to provide an overview of the cultural reality of lullaby, doda idi from Acehnese family habit. This study describes the cultural norms and values configuration viewed from an ethno-pragmatic perspective and the local wisdom identified from the discourse. This study presents the cultural script approach. This approach is a descriptive technique that has grown out of the cross-cultural semantic theory proposed. The cultural discourse analysis of norms and values on natural semantic meta-language theory. It is considering that cultural norms and values constituted rules and regulations in social communication interaction practices. This lullaby linked to particular ways of speaking in the family's private domain, in this case, from mother and her child. Generally speaking, most cross-cultural communication styles assume that within a particular speech community, there are certain shared understandings about how it is appropriate to speak in a particular and cultural situation. A certain methodological technique is adopted to describe speech patterns and identify the relevant cultural values of this speech pattern. The proposed Acehnese cultural script is linked with (1) Showing high respect, (2) patriotic spirit, and (3) giving advice. The configuration of these cultural norms and values is the understanding of knowledge and wisdom in terms of the lullaby system. The configuration is constructed in low-level scripts with lexicons in semantic primes.
\end{abstract}

Keywords - cultural norms and values, configuration, cultural scripts, natural semantic metalanguage, semantic prime.

\section{Introduction}

Acehnese language is one of the indigenous languages in Indonesia spoken by the Acehnese community dwelled mostly in Aceh Province, in the north-western tip of Sumatra Island, and some other parts of Indonesia. Durie (1985: 3) claimed that Acehnese is a member of the Chamic branch of the Malayo-Polynesian language family. Acehnese language plays various functions in the community; they are as a local language and as the identity of the Acehnese people. Furthermore, the Acehnese language also can unite the Acehnese people as a means of communication and verbal interaction, and to record and transmit the culture from one generation to others in various aspects, and those are regarded as the essential function among the community. 
In another word, Acehnese has been used in various domains of life. It is also specifically used in the family domain to accompany a toddler to go to bed.

Doda idi is a traditional song performed in the activity to accompany children to lie down in the Aceh community. Doda Idi traditionally means to swing slowly. Doda Idi was derived from doda or peudoda means to swing, and idi or dodi means to sway. The two words seem similar in meaning. Doda idi is actually a traditional poem of Acheh which is performed by giving a slow melody or a hum.

Similarly, with another traditional poem, the creator of doda idi is also unknown (anonymous). The rhyme of the doda idi was arranged in four lines every couplet, ending by a-a-a-a or a-b-a-b. Every rhyme contains meaning or message in which the speakers intended to deliver, in this case, a mother as a person who plays a role in guarding, taking care of, educating the children. In the poem of doda idi. This lullaby has a deep meaning to deliver a life lesson to the children from an early age. The message from Doda idi is dominated by Islamic stories and knowledge so that children get the Islamic knowledge and Aqidah earlier. However, this tradition is potentially going to be extinct, for it is rare to see a mother perform a lullaby to her baby (ies).

Consequently, the young generation has got a less moral and religious lesson from an early age. It needs to do complete documentation to preserve and maintain this tradition in line with this. This paper challenges and uncovers the link between particular ways of speaking and cultural values and attitudes of the people concerned from the lines of Doda Idi lullaby. Most studies of cultural discourses construct the pattern of speaking, norms of interaction, and discourse strategies to characterize shared understanding within the speech community. The new model of cultural scripts developed by Anna Wierzbicka (1994a, b, c) was applied to uncover the way of speaking and the Acehnese cultural values and norms.

The present cultural scripts model is framed within a theory of natural semantic metalanguage (NSM) approach and methodology, which was originated by Anna Wierzbicka (1972, 1992a, 1996, Goddard and Wierzbicka 1994, 2002 cf Goddard 1998a). The cultural scripts are regarded as a comprehensive approach to such a crosscultural semantic analysis as the objective of this paper. Goddard (1997) shared a conventional metalanguage set of terms, which are used to describe cultural norms of communication; they are "directness", "formality", "politeness", "involvement", "face" and so on. However, such terms can be criticized as being vogue. It is because those terms deliver different meanings proposed by different authors. Goddard (1997) gave examples that Japanese prefers "indirect" rather than English "direct". The key to overcoming this problem is to use the natural semantic metalanguage (NSM), as developed by Anna Wierzbicka and colleagues, who have been doing semantic analysis for many years. This consists of a small set of simple meanings expressed by words or bound morphemes in all languages, for example, PEOPLE, SOMEONE, SOMETHING, THIS, SAY, THINK, WANT, KNOW GOOD BAD, NO. These are the universal lexicons, which means those lexicons can be translated precisely in all languages. Those lexicons combine according to a small set universal grammatical pattern, which is an ideal equipment for cross-linguistic semantics. Most empirical semantic analysis has been conducted using the NSM approach, which focuses on keywords, speech act, and discourse particles (Goddard, also, 1992, 1994, 1996; Wierzbicka, 1991, 1992, 1996 in Goddard 1997) 
The universal lexicons of metalanguage can be used for semantic analysis and to formulate cultural rules (which Wierzbicka says as cultural script). Due to phrasing in simple and translatable terms, such script can achieve a high precision while minimizing the ethnocentric bias creeping. The following is a simple example of a Japanese cultural script (cf. Wierzbicka, 1994 a).

If something bad happens to someone because of me

I have to say something like this to this person:

"I feel something bad because of this"

Using the NSM for lexical semantics and cultural scripts makes it possible to link between indigenous cultural values and cultural rules of speaking. Thus, this paper will propose the semantic explication for the Acehnese cultural script from the cultural lullaby Doda idi.

\section{Literature Review}

This paper is concerned with applying ethno-pragmatics perspective to the metalanguage of the semantic primes in the natural semantic metalanguage approach, which is one stream of cognitive linguistics. Ethno-pragmatics is understood to be intertwined with cross-linguistic semantics. Due to that, the whole idea of ethno-pragmatics to understand the speech practice relating to the people concerned. The speech practices concerned the indigenous values, beliefs and attitudes, social categories, emotion and so on (Goddard, 2015). Goddard (2004) sometimes called ethno-pragmatics with cross-cultural pragmatics because, according to Goddard (2004), the ethno aspect emphasizes the culture, and cross-cultural pragmatics emphasizes cross-cultural communication ethno-pragmatics can equally be done in a single language. It can be summed up that the tasks in ethno-pragmatic descriptions are to identify and describe the preferred style or pattern of speaking culturally and spell out these links. For example, much can be understood about Malay way of speaking concept, such as malu "shame, sense of propriety", maruah "personal dignity" (Goddard, 1996, 1997 in Goddard, 2015), Acehnese way of speaking, such as hormat "respect", harapan "asserting hope" (Pratiwy, 2019) and so on. Goddard (2015) suggests that the standard practice implied when to describe the speech pattern culturally is to employ the inventory terms such as: "directness", "politeness", and so on. Take "directness" as an example. This term can be valuable and useful in that it can imply different ways of speaking and meanings based on the background of the culture of the speakers (speaker's community). However, ethno-pragmatics also describes the differences in how, when and why to be "indirect" to give a complete understanding. Based on the concept of the frame of indigenous culture, people from different cultures will speak differently because they think differently, feel differently and interact differently. Wierzbicka (1999) gave an example of a cultural comparison between Anglo-America and Japan. The description showed the differences in their communication patterns. Anglo-Americans usually say as follows:

"I can do something very good" or

"I think this" or

"I think that"

Anglo-Americans regard it important to express their thought through lexicons while communicating with others. The message they deliver to the hearer should be clear, open and direct. They avoid using the lexicons which invite the implied meaning or ambiguous. They also avoid gestures or any non-verbal type of communication. Even the decline messages if they do not agree. The way of Anglo-American communication reflects their own culture. Indeed, the culture shows that people have the right to express what they feel and think. The expression of 
feeling and thought openly truly reflects their cultural habit. However, they never think that other people will agree with what they do. Instead, they also do not mind whether other people will oppose their speaking method. On the other hand, the Japanese apply a different way of communication from Anglo-Americans. It seems that they will say:

"I cannot say this to other people."

"I think like this" or

"I don't think like this"

It is better not to say what they think to other people for the Japanese. They are trained to communicate by anticipating people's feelings and hope without expressing them verbally. Their culture trained them not to ask explanations and decline aggressively. Japanese cultural norms are different from Anglo-Americans, and it is reflected in their communication pattern. It is in line with Wierzbicka's formulation (1999) in her Cultural Script, in which it will describe the way people think in formalizing their communicative pattern.

Following Goddard (2004), the solution to overcoming the problem of describing the values and attitudes based on speech pattern culturally is by applying the Natural Semantic Metalanguage (NSM) theory originated by Anna Wierzbicka and colleagues over many years of cross-linguistic semantic research (see Goddard, 2004; Goddard \& Wierzbicka, 2004; Goddard \& Wierzbicka, 2007 Eds). Wierzbicka (1996) understood NSM as a decompositional system of meaning representation, which was based on empirically established universal semantic primes. In other words, NSM uses simple translatable words to clarify the meaning of complex-culture specific ones. The explication of NSM can capture the meaning from an insider perspective, as well as it can be translated cross-culturally and other language speakers can understand (Goddard and Wierzbicka, 2014). Wierzbicka offered the small set of simple, basic meanings (semantic primes) as the core lexicons of every language, which cannot be further illustrated without circularity. These can employ simple culturally shared meaning, as shown below.

\begin{tabular}{|l|l|}
\hline \multicolumn{1}{|c|}{ Category } & \multicolumn{1}{c|}{ Primes } \\
\hline Substantives & I, YOU, SOMEONE, PEOPLE, SOMETHING/THING, BODY \\
\hline Relational Substantives & KIND, PART \\
\hline Determiners & THIS, THE SAME, OTHER ELSE ANOTHER \\
\hline Quantifiers & ONE, TWO, SOME, ALL, MUCH/MANY, LITTLE/FEW \\
\hline Evaluators & GOOD, BAD \\
\hline Descriptors & BIG, SMALL \\
\hline Mental predicates & THINK, KNOW, WANT, DON'T WANT, FEEL, SEE, HEAR \\
\hline Speech & SAY, WORDS, TRUE \\
\hline Actions, Events, Movement & DO, HAPPEN, MOVE \\
\hline Existence, Possession & $\begin{array}{l}\text { BE (SOMEWHERE), } \\
\text { (SOMEONE/SOMETHING), (IS) MINE }\end{array}$ \\
\hline Life and Death & LIVE, DIE \\
\hline Time & $\begin{array}{l}\text { WHEN/TIME, NOW, BEFORE, AFTER, A LONG TIME, A } \\
\text { SHORT TIME, FOR SOME TIME, MOMENT }\end{array}$ \\
\hline Space & $\begin{array}{l}\text { WHERE/PLACE, HERE, ABOVE, BELOW, FAR, NEAR, SIDE, } \\
\text { INSIDE, TOUCH (CONTACT) }\end{array}$ \\
\hline Logical Concepts & NOT, MAYBE, CAN, BECAUSE, IF \\
\hline Intensifier, Augmentor & VERY, MORE \\
\hline Similarity & LIKE/AS/WAY \\
\hline
\end{tabular}

Table 1. A chart of Semantic Primes 
The basic grammar of vocabulary can govern how the primes can be combined, so the system is supposed to clarify all the complex word meanings found in any language.

The other important point to be discussed is the cultural script as the element being analyzed that people can capture the particular cultural values. The cultural script plays an important role in ethno-pragmatics, for it is one of the key techniques for ethno-pragmatics. The cultural script exists in three aspects: thinking, speaking, and behaviour. The cultural script also exists in different levels of generality, high-level scripts (termed as master scripts) and lowlevel scripts. High-level scripts are closely associated with the cultural keywords, such as hormat "respect" and harap "asserting hope" in Acehnese, as follows:

[A] Someone thinks like this:

When someone does something, it is good if he can think like this:

"I do this because I want to do it and because this is something polite."

[B] Someone thinks like this:

That is good if someone wants the other person to know what someone thinks.

"I feel something good because of this"

It is seen that the above scripts are constructed by various evaluative components, such as "it is good if" with its variants "it is not good if", "it is bad if", "it is not bad if", It can be good if" and "it can be bad if". Many cultural scripts are in this format. For lower-level scripts, they are often introduced by the components "when" and "if" representing aspects of social context.

Various studies adopting ethno-pragmatics and its "partner NMS" in their approach are largely used in analyzing cross-cultural aspects of language. In the same year (2015), Goddard published his two researchers, which both of them adopted ethno-pragmatics with NSM to analyze the problem data.

\section{Research Method}

This study was designed in synchronic-ethnographic research. It describes language use, which covers the community's social and cultural aspects in certain speech events. This study follows the qualitative descriptive method by adopting the phenomenology approach from Creswell (1998). The data for this research was from Doda Idi text accessed from the internet. The data collected were analyzed by following the steps of the phenomenological approach, which can be summed up that every phenomenon expressed by the respondents relating to the text is described textually and structurally, which is supposed to get the entire and accurate meaning. To support the analysis, determining elements split and paraphrasing was implemented. The meaning could be internally interpreted within the language. Then The researcher analyzed the data following the formulation of the problems and research objectives. To get the precise meaning, the researcher also conducted the local wisdom discovered from the text in-depth interview with the informants who have deep cultural knowledge of Acehnese.

\section{Results and Discussion}

This part focuses on discussing the cultural values and norms found in Acehnese cultural song as a lullaby performed when a mother lies down the sibling in the cradle to get to sleep. One of the lullabies recognized in Acehnese ethnic is Doda idi. The lyrics and the rhymes can be seen below:

This lullaby's cultural values and norms can be determined by adopting a way of analysis following cultural scripts. The scripts are divided into two levels in general, high-level scripts (master scripts) and low-level scripts. Master scripts can be used as guidelines or models 
to uncover cultural values and norms.

Acehnese is one of the indigenous languages in Indonesia spoken by the Aceh ethnic. The traditional culture of Aceh (adat "custom") is embodied in many sayings and maxims, such as adat bak po teumeureuhom, hukom bak syah kuala, kanun bak potro phang, reusam bak Lakshmana. It delivers the meaning that the adat, which had not been stated conventionally, might be governed by the Sultan (Iskandar Muda, The King of Aceh Kingdom in the past), while the law of Islamic countries was governed by an imam (religious leader) from Ulama (Islamic scholar). This adat expression reflects the bound condition between cultures and Islamic rules and values in the life of Acehnese people. Some cultural values are embodied in its lullaby, named Doda Idi, as seen below.

\title{
Showing High Respect to The Lord of the Universe and His Prophet.
}

Respecting God as the Lord of the Universe Who is in His hand the fate and destiny of human being implies several things in community and culture. First, it implies obedience to the entity Who is regarded glorious, the entity Who protects and governs the life of the Universe. Furthermore, the love for the Prophet Muhammad is also echoed many times in the lyrics. It is reflected in the very beginning of the lullaby, as seen below.

\author{
Lailahaillallah \\ Nabiyullah ka neuwafeut \\ Leupah nabi neuwoe bak Tuhan \\ Tinggai Kuru`an deungon seulawuet \\ ( La ilaha illa'llahu \\ The Prophet has passed away \\ The Prophet has come back to Allah, God \\ To leave behind the holy Qur'an and seulawat)
}

The name of Allah is echoed many times at the beginning of every stanza. It symbolizes that life with the Islamic soul is tied to the community's daily life. This lullaby was created to praise be upon the Lord first; then, it was created to deliver the lessons of Islamic religion to the baby at an early age or from the very beginning of life.

The other implication is that it is considered a symbol of close relationship and politeness to the entities Who are regarded as having a high position in the life of the community, the God and the Prophet. This symbolic meaning indicates the harmonious relationship among the entities in the community. Muslims need to lean whatever things they have to God's fate and fortune. Furthermore, the shafa'at from the prophet will be needed in the other life. These two things are tried to be infused into the mind of the children from an earlier age. Thus, the producer of the text thinks that she has to say or sing like this as in the lullaby. This is the kind of low-level scripts, as suggested by Goddard (2004), that the cultural scripts can be expressed, which apply the components "when" and "if". It is the model of cultural norm configuration of respecting other entities. The speaker believes something good will happen accordingly. The respects include the aspect of thinking, saying and doing. They think they should respect other entities, and it reflects in the Acehnese Lullaby Doda Idi. Acehnese cultural norms are figured out below:

If I do this to someone, I believe someone can give something good in the result.

It is not something bad that will happen.

It would be better if I did this "I think I should do this"

It is true that the word respect "hormat" becomes the cultural keyword of the cultural script in Acehnese (see Goddard, 2004; Pratiwy, 2019); in this case, the respect goes to the Almighty God and His Prophet. 


\section{Patriotic Spirit.}

Various sources claimed that Acehnese was figured out as a patriotic character. It is proved that there are so many historical sources in Indonesian history that documented the patriotic story from Aceh. In line with this, the very outstanding tale of Hikayat Prang Sabi (see Kulu, 1980) told about the story of war conducted by the Acehnese people once upon a time to defend the country from the kafir colonial that has been known mostly to Acehnese people. The spirit to defend the nation is together with the trial to defend their religion. They keep the faith as tight as they can. The quotation which shows this spirit from the second stanza of the lullaby is as follows:

Do idi ku doda idang

Geulayang blang ka putoh taloe

Rayeuk sinyak Banta Seudang

Jak bantu prang ta bela nanggroe

(Do idi ku doda idang

The rope of the kite in the sky has been cut off

Grown up my child hurriedly, oh Banta Seudang!

Come and take apart to defend our country)

The spirit of defending the nation is repeated in the fifth and sixth stanzas.

Allah hai do doda idang

Seulayang blang ka putoh taloe

Beurijang rayeuk muda seudang

Tajak bantu prang tabela nanggroe.

(Allah hai do doda idang

The rope of the kite in the sky has been cut off

Grown-up my child hurriedly, oh Banta Seudang!

Come and take apart to defend our country)

Wahee aneuk meubek taduek le

Beudoh saree tabela bangsa

Bek tatakot keu darah ilee

Adak pih mate poma ka rela.

(wake up, child, don't sit again!

Stand up together to defend the country

Don't be afraid even your blood has been blended

Even if you die in the battle, I have been willing)

It uncovers the meaning that this spirit should be infused repeatedly to children from an early age. In particular, educating young people with patriotism may strengthen the feeling of a national religion. Patriotism is the feeling of love, devotion, and a sense of attachment to the homeland or a country and alliance with others who share the same sentiment to create a feeling of oneness among the people. Additionally, the spirit of defending the homeland and the religion of Islam in one-atmosphere colours the spirit of patriotism implied in the lullaby. In this case, the parents think that she needs to do it by echoing the baits, which are full of a spirit of patriotism while the child is going to sleep. Parents of Aceh ethnic believe that defending the nation and religion is one of Jihad ways of life. As stated before, almost 100 per cent of Acehnese are Muslims. They keep in their mind all the lessons from the Holy Qur'an as their guidance of life, including the jihad to defend the country. The cultural script can be figured out as follows: 


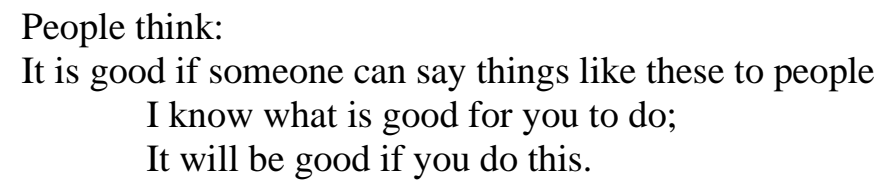

\section{Giving Advice}

The cultural script in this session concerns the importance of knowing how to act. Consistent with it, this lullaby reflects how habitually people in Aceh provide other people with the appropriate advice and guidance. One who advises other entities is under some conditions and reasons; (1) relationship, one who has a close relation to the entities who are supposed to receive the advice, (2) the entities are appropriate to receive advice, (3) the advice contains necessity or suggestion. Among such people can be counted that the mother, as the actor performs a lullaby, can provide this advice to her siblings through her lullaby. Acehnese people generally understand the appropriate time to give siblings advice when the child falls asleep. Within a family, mother and father are especially valued sources of advice.

Concerning habits stipulated in traditional rules and values, parents are supposed to advise the family members. The stanza of the lullaby, which contains the script of providing advice which is certainly needed to write this attitude towards the orang tua (mother and father):

Oh rayeuk gata, bungong jeumpa, aneuk rupawan

Meubek talawan, aneuk badan ayah deungon ma.

( Oh, when will you be grown up, Cempaka flower, my cute child

Don't fight against mother and father, our beloved soul)

The script which is appropriate for this stanza is as follows:

Everyone knows:

Older people know many things because they have lived for a long time;

Other people don't know these things;

It is good for other people if they can know these things

Allah hai do doda idi

Boh gadong bi boh kayee uteun

Rayeuk sinyak hana peue ma bri

Ayeb ngon keuji ureung donya kheun.

(Allah, God Almighty hai do doda idi

Gadong fruit and all the fruits from the forest

Be grown-up hurriedly; even mommy cannot give you anything

People always say disgrace and villain)

The rhyme suggests a further cultural script such as below:

People think:

It is good if someone can say things like these to people

I know what is good for you to do;

It will be good if you do this. I can say like this to someone as a human being,

The data show that the traditional habit of echoing a lullaby to children when accompanying them to bed gives some advice taking the form of suggestion. The mother thinks that she is worried about her child. The mother will be afraid that something bad will happen to her child. Therefore, the mother thinks that she should give advice. The meaning of cultural norms of giving advice can be figured out as follows:

I think:

I can say to someone like my child.

I say something like this to prevent my child from bad happen 
I believe that my child will follow what I have said "I give advice."

\section{Conclusion}

Some cultural scripts have been figured out through every bait of lines in the lullaby performed by (usually) a mother to her baby when he falls asleep. This study found some configurations of cultural norms from the lullaby. This lullaby reflects the cultural habit conducted by family in their home. Every bait in the stanza can be possibly and tentatively changed according to what things the performer wants to deliver to the baby to get the life lesson from it.

By applying the Ethno-pragmatic tool to analyze the cultural scripts from the cultural keywords, it can be formalized the meaning of cultural norms through the baits in the lullaby, which include: showing high respect to the Great Entity (God, The Almighty and the Prophet), patriotic spirit, and giving advice. The configurations of the semantic meaning of the cultural norms have been figured out based on the prime semantic prototypes.

\section{References}

Creswell, J. W. (1998). Qualitative Inquiry and Research Design: Choosing among Five Traditions. California: Sage Publication Inc.

Creswell, J. W. (2005). Educational Research Planning, Conducting and Evaluating Quantitative and Qualitative Research. California: SAGE

Creswell, J. W. (2009). Research Design Qualitative, Quantitative and Mixed Methods Approaches. California: SAGE

Durie, M. (1985). A grammar of Achehnese on the Basis of a Dialect of North Acheh. Netherlands: Foris Publication Holland.

Goddard, C \& Ye, Z. (2015). Ethnopragmatics. Routledge Handbook of Language and Culture. Edited by Farzad Sharifian, 66-83. Retrieved from https://www.academia.edu/10693895/Ethnopragmatics

Goddard, C and Wierzbicka, A. (2004). Cultural Scripts: What are They and What Are They Good for. (online) Retrieved from https://www.researchgate.net/publication/ 249939883 Cultural scripts What are they and what are they good for

Goddard, C and Wierzbicka, A. (2007). Semantic Primes and Cultural Scripts in Language Learning and Intercultural Communication. Retrieved from https://www.researchgate.net/publication/265204212_Semantic_primes_and_cultural_scr ipts in language learning and intercultural communication

Goddard, C. (2004). Cultural Script: A New Medium from Ethnopragmatic Instruction. In Cognitive Linguistics, Second Language Acquisition, and Foreign Language Teaching. Edited by Michel Archard and Susanne Niemeier. Berlin: Mouton de Gruyter. 145-165. Retrieved from https://www.academia.edu/17366268/Cultural_Scripts_ a_New_Medium_for_Ethnopragmatic_Instruction

Kulu, T. C. P. 1980. Hikayat Prang Sabi (versi latin). Salinan Anzib. Jakarta:Proyek Penerbitan Buku sastra Indonesia dan Daerah.

Netra, I.M. (2011). Configuration of Cultural Norms in Traditional Rice Planting Ritual Discourse the Traditional Farming Community of Bayan, North Lombok. Retrieved from https://ojs.unud.ac.id/index.php/eol/view/4572 